\title{
Impact of Social Media Marketing on Brand Love: Promoting Loyalty in the Restaurant Landscape of Pakistan
}

\author{
Mohammad Danial Ibrahim Sikandar \\ MBA Student, Department of Management Sciences, Bahria University, Islamabad, PAKISTAN \\ (D) 0000-0001-7518-2556 \\ danialibbi@gmail.com
}

\section{Qazi Mohammed Ahmed}

Assistant Professor, Department of Management Sciences, Bahria University, Islamabad, PAKISTAN

(D) 0000-0002-9237-3116

๑hmedqazi@hotmail.com

ARTICLE INFO

Received: 17 July 2019

Accepted: 2 October 2019

Published: 7 October 2019

DOI: https://doi.org/10.29333/ojcmt/5953

ABSTRACT

This research discusses the impact of social media marketing on establishing brand love and the mediating effect of brand love on promoting brand loyalty in the restaurant landscape of Pakistan. The major focus of carrying out this research was to analyze how different social media advertising elements have a profound impact on establishing brand love and how it leads towards promoting brand loyalty. This research includes three independent variables, one mediating variable and one dependent variable. The independent variables included Word of mouth, trendiness and customization. The mediating variable was brand love and the dependent variable was brand loyalty. The collection of the data was carried out through an online questionnaire made on Google forms and had 303 respondents. The data collected was analyzed through software called SPSS, and different statistical tests such as Cronbach's Alpha, correlation and regression and Hayes Process to test mediating effect were conducted. The results of these tests indicated that the elements Word of Mouth (WOM), Trendiness and customization do play a major role in establishing brand love and loyalty. The study could be further improved if we include more variables for analyzing the impact of social media.

Keywords: brand loyalty, brand love, social media marketing, Word of Mouth (WOM)

\section{INTRODUCTION}

Social Media Platforms are currently the center for marketers, and empowers them to identify and segment their consumer profiles, to have a rundown of the objective market they need to draw in with, and furthermore enables them to see and explore their very own rundown of associations and in some cases the associations made by others in the framework. The idea of giving various types of marketing efforts contrasts from site to site. For example, Twitter, Facebook, MySpace, have their own specific manners and terms and conditions for promoting. 
The fundamental motivation behind applying post-modern marketing practices to social media platforms is to establish trust between the brands and the clients. By establishing trust among clients tends to influence their conduct, and they create inspirational state of mind towards the brand. Also, such clients spread positive verbal exchange for the organization, which helps in expanding its image value. Consequently, for marketers to draw in more purchasers it is vital that their clients have an offline consciousness of the brand as well with the goal that brand's online existence is noticeable to them. Numerous research studies have proposed that Facebook is utilized to fortify existing association's offline, and these connections might be frail now and again however the majority of the occasions there is some disconnected component offline among the brand and client, when he looks for the organization on the web.

It has been researched that Facebook clients tend to scan for the brand they have an association with offline contrasted with searching for totally unheard-of brands. Numerous organizations are overwhelmingly rehearsing various distinctive things using innovation and new technologies to draw in new buyers, give better service experiences to the current clients, and generate higher profitable sales and to portray a better brand image

The platforms of Social Media help individuals to have communication with each other. The clients share a considerable measure of data about their interests and about various items and administrations offered by various associations. It is outstanding amongst other promoting practices and the marketing mix can be applied very effectively in order to establish a strategic competitive benefit to stand out from the competition. The clients make their own profile, communicate with individuals with whom they can convey and look through the data given by them. Individuals who search for data or item suggestion before purchasing any item have likelihood of purchasing that.

Facebook is an online platform that has enabled masses to develop their open profiles to set up an association with other individuals utilizing person to person communication locales. Remembering that Facebook has a tremendous clientele, based the majority of which are baby boomer generation, that are intrigued to find out about new items in market has given sponsors the plan to impact or influence customers towards their items and go along the data to others that establishes the framework of viral promoting. Buyers can likewise join mark related gatherings on Facebook which may impact their image discernment and at last their buy choices. The purchasers typically get data through other gathering. In the meantime, the sponsors additionally get the chance to go along their contact to their intended interest group. Purchasers turn in enormous numbers to Facebook bunches as confided in wellspring of data, which makes new open doors for marketers to build relationships between consumer and brands.

There are numerous platforms in Social Media through which individuals are able to connect with one another. Facebook was propelled into existence in the year 2004, and has more than 1 billion dynamic clients. Instagram came into being in 2010; by the year 2014 it had over one hundred and eighty million clients who refreshed 70 million photographs and recordings for every day, with normal 130,000 clients for every week. In March 2006, Twitter came into existence, and in 2010 it had 30 million dynamic clients, who sent 50 million tweets for each day, and normal 370,000 new clients for each day and earned around 45 million dollars as income. Facebook acquired Instagram in 2012 for 1 billion dollars. Another social media platform that is becoming increasing popular these days is Snapchat. This particular platform came up with the amazing idea of disappearing posts. This resonated highly with its consumer market. It was propelled into existence in 
Online Journal of Communication and Media Technologies, 2019

September 2011, it has evaluated 200 million clients who send around four hundred million snaps for every day.

In Pakistan, the hype for Social Media Marketing seems ever rising. Roughly 30 million have been accounted for to be online every day and this number is developing quickly. Correspondingly Pakistan is the fifth greatest cell phone grandstand in Asia with 120 million distinct endorsers. (Wilson, Gosling, \& Graham, 2012). At present Facebook is the greatest long-range informal communication site in Pakistan with more than nine million clients.

As per a report Facebook gets over 1,000,000 supporters every month, around 44 thousand new clients join the site on an ongoing basis. As mentioned in (Haque \& Popalzai, 2013). In 2013, the Facebook crowd had 70\% males and $30 \%$ females. The concept of brand love is a basic but imperative one that focuses upon brand emotions, passion, attachment and declarations (Albert, Merunka, \& Valette-Florence, 2008) it in this manner helps constructs a relationship between the brand and the consumer (Kohli, Melewar, \& Yen, 2014). (Albert, Merunka, \& Valette-Florence, 2008) and (Sternberg, 1997) has affirmed that brand decision, commitment, liking etc are all identified with brand love. Inside the setting of online network-based networks, scientists (Vernuccio, Pagani, Barbarossa, \& Pastore, 2015) (Wallace \& de Chernatony, 2014) (Wallace, Buil, \& de Chernatony, 2017) have analyzed the "like" capacity of the pages on Facebook to be an outflow for the love of the brand from the shoppers, who are following updates of the online page of the brand. It displays their relationship with the brand on a much deeper and emotional level.

The purpose of this research is to delve deeper into the mindset of the Pakistani consumer, understand the buyer buttons and help promote brand love and loyalty in the restaurant industry in Pakistan. Pakistan is a country that celebrates its rich heritage and displays its immense love for food and thus the restaurant industry is a highly competitive one with cut throat competition, with every brand trying to put their best foot forward and resonate with the customers at a much more personal level and help interact with them and reach them above the sensory threshold which has been numbed by the cornucopia of various advertisements and choices thrown at the modern day consumer.

\section{CONCEPTUAL DEVELOPMENT AND HYPOTHESIS}

\section{Social Media and Restaurant Industry}

In the study, numerous studies have tended to shorter sustenance supply chains from a homestead point of view, while others have concentrated their examination on analyzing drivers and conduct of shoppers towards condensed nourishment supply chains (Aiello, Giovino, Vallone, \& Catania, 2017). A large portion of these studies inferred that the principle explanation behind purchasers' hesitation is the concern for the quality. In this sense, the buyer, can get items implanted with data around creation framework, beginning and particular quality. This would encourage them to make esteem judgments about the item.

Moreover, the diminished separation between the essential maker and the last customer would improve the formation of shared trust (Mundler \& Laughrea, 2016). Accordingly, it would act as an awesome incentive for endeavors to play a part in this type of marketing. Albeit's marketing of the social media is an all-around concentrated concern, which, to the best of our insight no research has tended to the capability of the social media to be utilized as the short nourishment supply chains. As indicated by the 
creator, making on the web short nourishment supply chains utilizing social systems should be a changing diversion in the future in the social media marketing. The vital job of shoppers all through the whole of the social marketing mechanism drove the exploration gathering to design the flow inquire about as a purchaser centered investigation. Because of the curiosity of the point, subjective examination (sentence finishing and free posting strategies) has been embraced in this exploration.

The primary target of this examination is to get a buyer's culturally diverse understanding on the capability of utilizing social systems administration destinations as short nourishment supply chains (Elghannam, Arroyo, Eldesouky, \& Mesias, 2018). To this end, it was chosen to apply the survey in three unique nations, to be specific, Mexico, Egypt, and Spain. Every one of them are altogether distinct from each other as far as area, culture, dialect, financial level, populace, web utilize and even as far as purchaser use, which makes them unmistakably fit in with the targets of the investigation.

In light of the remarkable difficulties of the food business is confronting, (Kerr, Mortimer, Dickinson, \& Waller, 2012) investigates blogger buzz in response to organization public statements on wellbeing and stoutness problems in the industry of food. The creator center around blogging, which has turned out to be more essential in showing purchaser control throughout the years. Since the most utilized methodologies by the eatery industry to the basic buyers' translations of organizations' exercises and qualities are item and advancement, the creator utilized these two divisions to fundamentally analyze the reactions of the blogger and their feeling towards the CSR. 1) What are the wellbeing practices linked to the CSR rehearses that has been conveyed by these eatery organizations? 2) Which sorts of the CSR activities have produced mindfulness among the bloggers? 3) What are the reactions of the bloggers towards these communications of the CSR? 4) Who are the bloggers that take part in the exchanges?

The investigation reacts to require a superior comprehension of the CSR interchanges in enterprises and the organizations that are contrarily connected with the social, ecological and moral problems (Du \& Vieira, 2012). It centers around a particular arrangement of problems looked by organizations for which the CSR concerns straightforwardly identify with their center business exercises. The author (Lee, Van Dolen, \& Kolk, 2013) likewise include a novel perspective CSR mindfulness investigate by exactly investigating bloggers' reactions towards CSR activities. The author meant to give contribution to the more extensive discussion in regard to the (future) job of the social media included in the dependable business by contributing bits of knowledge from one and only kind of online response.

The use and significance of the social media is quite crucial in the eatery industry in order to upgrade business nearness, footfall and income (Edalat \& Morris). Therefore, in this way it is quite significant for eateries to comprehend culture while implementing the social media. The eatery business can use the social media to amplify assets, enabling the restaurants to accumulate data with respect to the visitor profile which will aid income administration when advancements for unique menus, things and occasions are utilized with the end goal to draw in visitors to visit the place.

There is absolutely no question that the nexus of marketing transverses from the traditional onset of marketing to the digital mode in this postmodern era for this everevolving landscape of restaurant industry. Formulated on the given studies, the research offers the hypothesis as stated below: 
H1: There is a significant positive relation between brand love and brand loyalty in the restaurant landscape of Pakistan.

\section{Social Media and Brand Love}

In social setting and this field where the risk is the improvement of reasonable connections among the partners and its brand, the most essential inquiry is regarding "how do partners identify with brands" (Kaufmann, Loureiro, \& Manarioti, 2016). Scientists have proposed diverse variables to be critical for this relationship, from the identity of the brand and the degree to which it communicates the estimations of purchasers (Wallace \& de Chernatony, 2014) to the reliability of the brand. From a more transformative perspective, the author portrays this customer mark relationship as a three-level build: protest focused commitment, egotistical commitment and social commitment.

Those "layers" mirror a concern that diverse necessities, thought processes and objectives result in various mental layers of commitment. In the primary level, the consumer- mark relation is practically determined commitment; which is, the customer "secures data about the brand with the objective of getting utilitarian advantages from the brand" (Schmitt, 2012). In the next level, the brand is identified with the character of the purchaser, though on the very next layer, the brand gives a feeling of network.

The love for the brand (Brand Love) is still a new idea in the exploration channel of customer- mark connections, with a wide scope of optimistic expressions and demeanors towards the brand (Batra, Ahuvia, \& Bagozzi, 2012), that clarifies and foresees variety in alluring post-utilization practices among fulfilled customers.

Researchers recognize the attributes of brand love by proposing diverse arrangements of components, contingent upon their particular meaning of the idea. The most wellknown methodology is to link mark love to the relational love and endeavor to implement terms and meanings of the last to mark love because of the major similitudes among those ideas (Langner, Bruns, Fischer, \& Rossiter, 2016). In spite of the fame of this methodology, there is some feedback center around key contrasts among the brand and the relational love, beginning from the finding that shoppers don't utilize the correct word "love" while portraying their sentiments towards a brand, except if the specialist expressly requests that they do as such. Also, two central contrasts between the two builds are, as indicated by (Batra, Ahuvia, \& Bagozzi, 2012) 1) Although relational love has a tendency to be benevolent and unqualified, members in their examination reported this isn't valid for brand love - purchasers accept apparent greatness as an essential. 2) Contrary to relational love, mark love is where correspondence isn't considered as compulsory, in light of the fact that brands are not anticipated that would demonstrate "feelings".

Indisputably, when a brand speaks to values that are consistent with the shoppers' conviction framework, when it exhibits qualities that upgrade the purchasers' social substance and their mental self-view and when it is identified with solid and important mental portrayals, this connection between the customer and the brand can be as solid, persevering and great as affection. Even though vast study has been done on the webbased marketing techniques, there is still presently a break in the available literature relevant to the efficacy of utilizing the social media networking for the destination hotels as a marketing tool. The main aim of (Virginia Phelan, Chen, \& Haney, 2013) the research is to analyze how hotels utilize the features of Facebook as way of giving property info to consumers. Furthermore, interaction of client, such as the recurrence of the clients' comments, and the feedback collected from the organization's member, and 
intercommunication (e.g. the location based "check-in" and the number of "like") are viewed and assessed. Previous researches have depicted that the social media existence of a hotel does not only has to make an "impact" to attract the potential buyers, but even over and above crucially, it should create "relations" with them. It analyses the pattern of Facebook used by the hotels, how the hotels utilize the Facebook features in order to connect to their potential clients, and how the hotels grasp the power of the social media to boost the attempts of the social media marketing.

The discovery gives out important information for hotels to evolve their corresponding marketing strategies via the use of the social media as a platform to connect with clients and expand the hotel service delivery. If the hotels want to avail the social networking as a way for reaching out to clients and boost their business, they should at first understand the dynamics of the online climate and how the networking in the social media can help aid the marketing strategies. By evaluating the performance of the social media, the hotels may face some difficulty and lighten their current marketing acts. Furthermore, hotels can intensify the impact of their social networking prowess and differentiate themselves as the leading force within the competitive lodging market.

The current literature (Kaufmann, Loureiro, \& Manarioti, 2016) still does not effectively differentiate amongst the love feelings and the connection of love. The feeling of love is a unique, particular emotion, close to affection, which, a lot like all other emotions, is very precise. In contrast, the connection of love, is like the friendship relation, which persist for a prolonged time and indulges with various affective, intellectual, and behavioral practices. The existing brand love study examines the emotions of love and at times analyzes the relationship of love, but it hardly recognizes the difference. Thus, after reviewing the literature, the following hypothesis is proposed:

$\mathrm{H} 2$ : There is a positive impact of social media marketing on Brand Love in the restaurant landscape of Pakistan.

\section{Brand Love and Brand Loyalty in the context of Social Media}

Brands play a focal job in merchandising and have pulled in the consideration of scholastics and professionals over numerous years. Appropriately, a few points of view on the brands has been found in the writing. Generally, a brand is described as "a term, symbol, name, design, or any feature that classifies one seller's services or goods as different from those of other sellers". As per this methodology, the brand is seen as a feature of an item, and the fundamental capacity of the brand is to recognize a company's item from contending items, i.e. it is a classifier.

Subsequently, marketing exercises of firms have bit by bit concentrated more on the brand rather than the item, consequently, driving scholastics to find factors that comprise solid brands. In any case, such consideration has happened for the most part in the world created. Little study has been given to the problem in developing markets. Likewise, duplication inquire about assumes a vital job in science. It is a fundamental piece of learning improvement, all things considered, it is seldom embraced in the social sciences, particularly in business look into. Replication examines have discovered that various unique models were not bolstered. This would conclude in the seclusion and the disintegration of the literature.

The study of Nguyen, Barrett, \& Miller (2011) struggles to bond this gap of examining key antecedents of loyalty of the brand in two evolving markets: Vietnam and Thailand. In particular, it thoroughly analyzes the job of publicizing mentalities, circulation power, 
Online Journal of Communication and Media Technologies, 2019

brand mindfulness, and saw trait on the loyalty of the shopper to global brands in these two places.

Seen quality depends on the intuition of purchasers about the properties of a brand that is significant to them, i.e. it is an observation. At the point when customers see that the brand has amazing contrasted with different varieties in a focused set, they are probably going to put a greater incentive on that variety, driving their buy and repurchase choices. Be that as it may, as made reference to already, buyers can't see the nature of the brand in the event that they are unfamiliar about it. Subsequently, mindfulness may enable customers to get comfortable with the brand.

Further, commonality can support purchasing choices, particularly for lowcontribution items. Additionally, it tends to be contended that mindfulness is important to empower shoppers to separate a brand's traits from its contending varieties. At the point when customers assess a variety in connection to different varieties in the aggressive section, they perceive the distinctions amongst them. The communications between brand conduct and shopper conduct could be relied upon to make a solid full of feeling tie with the brand.

Speaking to a standout amongst the most imperative components accepted to clarify shopper brand decisions, it is nothing unexpected that the idea of brand loyalty has stirred a colossal enthusiasm among scholastics and also experts inside the field of marketing and customer conduct. Firms with extensive gatherings of steadfast clients have been appeared to have huge pieces of the overall industry, and piece of the overall industry, thus, has been appeared to be related with higher rates of degree of profitability (Møller Jensen \& Hansen, 2006). The author proposes that the loyalty of the brand favors the optimistic word of mouth and more prominent opposition among faithful clients to aggressive systems. Clearly such discoveries urge advertisers to fabricate and keep up brand loyalty among clients. When making progress toward such objectives, data on elements deciding the production of brand loyalty among clients turns into an imperative issue.

This study also explores the significance of the relative demeanor to the assurance of brand loyalty. Moreover, by analyzing the relative mentality as a forerunner of continue obtaining we expect a determinist way to deal with brand loyalty instead of the more conduct situated stochastic methodology. From an absolutely stochastic methodology, brand loyalty is viewed as equivalent to continue acquiring and grounded on no show factors deciding the conduct. It is difficult to distinguish any forerunners of rehash buys, and along these lines, organizations gain no comprehension of how to manufacture brand loyalty. From a determinist approach brand loyalty is conceptualized more like a disposition or expectation to buy and it is trusted that the analyst can explore the variables delivering brand loyalty. Advertisers exploring these components may in this way increase significant bits of knowledge into the creation and holding of brand loyalty among clients.

When considering buyers' assortment looking for conduct, it is vital to recognize "genuine" assortment looking for conduct from outwardly inspired brand exchanging. The creator contends that brand exchanging conduct should just be credited to genuine assortment looking for when variety is gone for its own natural esteem and for the incitement it conveys to the circumstance. Purchasers' requirement for something to decrease fatigue or a requirement for tactile incitement by investigating new item variations (e.g. a contrastingly seasoned espresso) are precedents of genuine assortment 
chasing. This gives observational proof to assortment looking to be more probable when association is lower, when littler brand contrasts are seen among decision choices and when buyers brand inclinations are lower.

H3: Brand love mediates the relation among the social media marketing strategies and brand loyalty in the restaurant landscape of Pakistan.

\section{Theoretical Framework}

After reviewing the aforementioned literature, the following theoretical framework is proposed. There are 3 independent variables proposed which include WOM, Customization and Trendiness. The dependent variable is Brand Loyalty and the research incorporates a mediating variable i.e. Brand Love which mediates the relationship between Social Media Marketing activities and Brand Love.

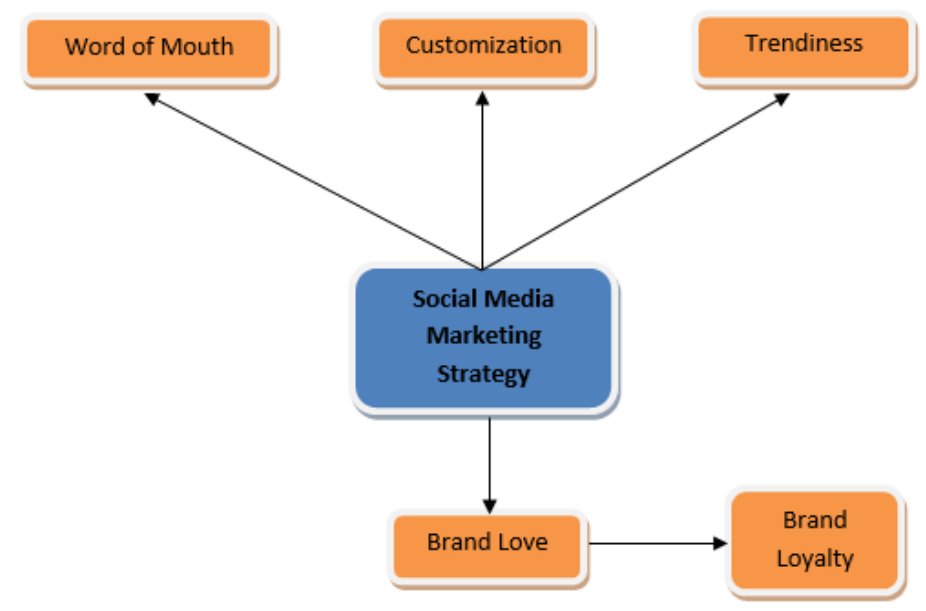

Figure 1. Research Model

\section{METHODOLOGY}

\section{Context}

The primary motivation behind carrying out this research is to observe the effects of social media marketing on establishing brand love and there forth promoting brand loyalty. 3 variables of SMMS have been selected to observe their impact on establishing brand love. These include WOM, Trendiness and Customization. It is critical to observe the effect of these marketing activities on different social mediums and their role in establishing brand love and loyalty. The restaurant landscape of Pakistan is experiencing a large boom presently and this research would be highly beneficial for the promotion of various restaurants.

\section{Data Collection and Sample}

The questionnaire was designed on the digital medium using Google Forms in order for ease of collection. Emails were sent out as well and Facebook was utilized to circulate the questionnaire for to assist the progress of the collection of data. There were a total of 25 questions and is based on the 5-point Likert Scale which consists of Strongly Agree, Agree, Undecided, Disagree and Strongly disagree as options. The sample size selected was of 303 participants out of which all 303 were validated.

The method of sampling selected was convenience sampling due to the limitations of the researcher. Convenience sampling is a random method of non-probability sampling and this form of sampling is most frequented by researchers due to it providing much ease to the researcher. (Farrokhi, F., \& Mahmoudi, 2012) 
The researcher has utilized the online medium for his data collection techniques and the respondents filled out the questionnaire online on Google forms and thus this online medium was deemed most suitable for the requirements and constraints of the research. As stated in a survey, Pakistan consists of 29.13 million internet users which are highly active out of which 23 million are active on social media and 19 million are mobile-social users which are active (Kemp, 2016). The statistics have been kept in mind to capitalize on the recent advances in the accumulation of data.

\section{Measures}

All data was collected with the help of a questionnaire adapted from the research of Raed Salah Algharabat (2017) regarding the link between social media brands and brand love. His research focused upon the mediating role of self-expressive brands whilst this particular research was primarily focused on the mediating effect of brand love between social media marketing and brand loyalty in the restaurant landscape of Pakistan.

\section{Data Analysis}

In order to fully analyze the data collected, the analysis was conducted on SPSS and tests for Hayes Process, Regression and Correlation etc. were run in order to fully scrutinize the details of this research. Numerous tutorials were consulted online in the process and all results were obtained. Graphical data was collected through Google forms and SPSS as well to graphically depict the customer behavior.

\section{RESULTS}

\section{Respondent Profiling}

A questionnaire was developed and circulated amongst the selected sample population and then further analysis was applied using IBM SPSS. The selected scale for statistically measuring the responses was the 5 point Likert Scale. It had 5 options namely: Strongly Agree; Agree; Undecided; Disagree and Strongly Disagree. The first part of the questionnaire consisted of the demographic profiling thus the sample was analyzed according to Gender, Age, Education, Income and Marital Status.

Table 1. Gender Composition of Respondents

\begin{tabular}{llcccc}
\hline & & Frequency & Percent & Valid Percent & Cumulative Percent \\
\hline \multirow{3}{*}{ Valid } & Male & 144 & 47.5 & 47.5 & 47.5 \\
& Female & 159 & 52.5 & 52.5 & 100.0 \\
& Total & 303 & 100.0 & 100.0 & \\
\hline
\end{tabular}

The total sample size obtained was 303 participants out of which the validated data was proven to be the complete data set. The number of male respondents was 144 out of 303 participants which is $47.5 \%$ of the entire sample size. Similarly, the female population consists of 159 out of 303 participants which is $52.5 \%$ of the entire sample size.

Table 2. Marital status of Respondents

\begin{tabular}{|c|c|c|c|c|c|}
\hline & & Frequency & Percent & Valid Percent & Cumulative Percent \\
\hline & Married & 79 & 26.1 & 26.1 & 26.1 \\
\hline Valid & Unmarried & 224 & 73.9 & 73.9 & 100.0 \\
\hline & Total & 303 & 100.0 & 100.0 & \\
\hline
\end{tabular}

The next question was directed towards obtaining statistical data of the marital status of the overall sample population. The results indicated that 79 participants $(26.1 \%)$ of the population was married and 224 participants $(73.9 \%)$ of the population was unmarried. 
M. D. Ibrahim Sikandar \& Q. M. Ahmed

\begin{tabular}{|c|c|c|c|c|c|}
\hline & & Frequency & Percent & Valid Percent & Cumulative Percent \\
\hline \multirow{6}{*}{ Valid } & $18-24$ & 171 & 56.4 & 56.4 & 56.4 \\
\hline & $25-34$ & 89 & 29.4 & 29.4 & 85.8 \\
\hline & $35-44$ & 20 & 6.6 & 6.6. & 92.4 \\
\hline & $45-60$ & 17 & 5.6 & 5.6 & 98.0 \\
\hline & $60+$ & 6 & 2.0 & 2.0 & 100.0 \\
\hline & Total & 303 & 100.0 & 100.0 & \\
\hline
\end{tabular}

The next question in the questionnaire was designed to obtain information about the age of the sample population. 5 categories of ranges were given as options; this consisted of 18-24, 25-34, 35-44, $45-60$ and 60+. Out of the 303 participants, 171 participants were between the category of ages $18-24,89$ participants were between the category $25-34,20$ participants were in the category of 34-44, 17 participants lied in the $45-60$ category and the $60+$ category consisted of 6 participants.

Table 4. Qualification composition of Respondents

\begin{tabular}{|c|c|c|c|c|c|}
\hline & & Frequency & Percent & Valid Percent & Cumulative Percent \\
\hline \multirow{4}{*}{ Valid } & Masters & 121 & 39.9 & 39.9 & 39.9 \\
\hline & Bachelors & 170 & 56.1 & 56.1 & 96.0 \\
\hline & High School & 12 & 4.0 & 4.0 & 100.0 \\
\hline & Total & 303 & 100.0 & 100.0 & \\
\hline
\end{tabular}

The next question was designed to obtain the current educational level of the participants. Respondents were given three options, namely Masters, Bachelors and High School. Out of the participants 121 people were currently at the master's level or higher. 170 people had done their bachelors and 12 people were currently at the high school educational level.

\section{Reliability Analysis}

The Cronbach's alpha is a proportion of the reliability of the data internally, which demonstrates how intently a gathering of things are identified with each other. This is viewed as a proportion of reliability of scale. It is compulsory for the surveyors and analysts that they should evaluate the amount to stretch out intelligence and precision to the clarification of their information.

Table 5. Reliability Statistics

\begin{tabular}{lcc}
\hline Item Name & Cronbach's Alpha & N. of Items \\
\hline Trendiness & 0.700 & 2 \\
Customization & 0.732 & 2 \\
Word of Mouth & 0.731 & 2 \\
Brand Love & 0.715 & 9 \\
Brand Loyalty & 0.750 & 4 \\
\hline
\end{tabular}

The threshold value for Cronbach's alpha is generally established to be above 0.7 (Hair et al., 2016) in order for it to be reliable. Thus, the results are validated.

\section{Correlation}

The correlation analysis helps researchers form a relationship that occurs between the two variables, the dependent and independent. This gives the researcher a unique insight into the relationship of the two variables and thus helps form a conclusion accordingly. These correlations are used to narrow down a positive/negative relationship between the variables that are used in research. 
Online Journal of Communication and Media Technologies, 2019

\begin{tabular}{llccccc}
\hline Table 6. Correlation of Research & \multicolumn{1}{l}{} \\
\hline & & Trendiness & Customization & WOM & Brand_Love Brand_Loyalty \\
\hline \multirow{3}{*}{ Trendiness } & Pearson Correlation & 1 & $.488^{* *}$ & $.413^{* *}$ & $.320^{* *}$ & $.262^{* *}$ \\
& Sig. (2-tailed) & & .000 & .000 & .000 & .000 \\
& $\mathrm{~N}$ & 303 & 303 & 303 & 303 & 303 \\
\hline \multirow{3}{*}{ Customization } & Pearson Correlation & $.488^{* *}$ & 1 & $.319^{* *}$ & $.239^{* *}$ & $.307^{* *}$ \\
& Sig. (2-tailed) & .000 & & .000 & .000 & .000 \\
& $\mathrm{~N}$ & 303 & 303 & 303 & 303 & 303 \\
\hline \multirow{3}{*}{ WOM } & Pearson Correlation & $.413^{* *}$ & $.319^{*}$ & 1 & $.427^{* *}$ & $.290^{* *}$ \\
& Sig. (2-tailed) & .000 & .000 & & .000 & .000 \\
& $\mathrm{~N}$ & 303 & 303 & 303 & 303 & 303 \\
\hline \multirow{5}{*}{ Brand_Love } & Pearson Correlation & $.320^{* *}$ & $.239^{* *}$ & $.427^{* *}$ & 1 & $.276^{* *}$ \\
& Sig. (2-tailed) & .000 & .000 & .000 & & .000 \\
& $\mathrm{~N}$ & 303 & 303 & 303 & 303 & 303 \\
\hline \multirow{3}{*}{ Brand_Loyalty } & Pearson Correlation & $.262^{* *}$ & $.307^{* *}$ & $.290^{* *}$ & $.276^{* *}$ & 1 \\
& Sig. (2-tailed) & .000 & .000 & .000 & .000 & 303 \\
& $\mathrm{~N}$ & 303 & 303 & 303 & 303 & 303 \\
\hline
\end{tabular}

**. Correlation is significant at the 0.01 level (2-tailed)

By analyzing the above data is clear to see that there is a positive relationship between Customization and Trendiness, WOM, Brand Love and Brand loyalty. Trendiness has a positive correlation with brand love, WOM, customization and brand loyalty. Similarly, WOM has a positive correlation with Trendiness (0.413) and Customization (0.319), Brand love (0.427) and Brand Loyalty. These insights help specify the impact of one variable on the other. For example, it is clear to see that any impact on WOM would have a significant impact on Brand love. Identifying these relationships is key for any research.

Regression

Regression analysis is defined as a process of arithmetically categorizing out the variables which do have an effect on each other whether that impact is positive or negative. The number of betas depends upon the number of independent variables in the equation.

Table 7. Research Model Summary

\begin{tabular}{lcccc}
\hline Model & R & R Square & Adjusted R Square & Std. Error of the Estimate \\
\hline 1 & $.370^{\mathrm{a}}$ & .137 & .134 & .83442 \\
2 & $.392^{\mathrm{b}}$ & .154 & .148 & .82747 \\
\hline a. Predictors: (Constant), SMMA & & & \\
b. Predictors: (Constant), SMMA, Brand_Love &
\end{tabular}

This research revolves around 3 elements of Social Media Marketing, namely Word of mouth, customization and trendiness. The research analyzes their impact on establishing brand love and hence forth promoting brand loyalty. Thus brand love is taken as a mediating variable in this research and its mediating impact is analyzed in two ways. One is through establishing 2 models in regression, one pertains to the social media marketing elements direct impact on brand loyalty and one model includes brand love as a mediating variable. In the above mentioned table the value of $R$ indicates the percentage of how correctly the independent variables represent the dependent variable. The value of $R$ in this table is 0.370 for the first model and 0.137 for the next which shows a positive that there is a positive relationship and the effect of the mediator has enhanced this relationship. The reason of taking a square root is to get more exact results. The $\mathrm{R}$ Square value shows the amount of variability in the brand loyalty described by the variables; this value is 0.137 for the first model and 0.154 for the next. This indicates that a one unit change in the independent variables will approximately results in 0.37 units or $37.5 \%$ change in brand loyalty which is our dependent variable. The value of the $R$ square is 0.137 for our first model which has been enhanced by our mediator (Brand Love) to 0.154 .This shows us that $13.7 \%$ of variability is caused in brand loyalty solely by WOM, 
M. D. Ibrahim Sikandar \& Q. M. Ahmed

Customization and Trendiness. The value of $\mathrm{R}$ square lies between 0 and 1 , and implies that the independent variables are good at predicting consumers' inclination.

Table 8. ANOVA

\begin{tabular}{|c|c|c|c|c|c|c|}
\hline Model & & Sum of Squares & df & Mean Square & $\mathbf{F}$ & Sig. \\
\hline \multirow{3}{*}{1} & Regression & 33.234 & 1 & 33.234 & 47.732 & $.000^{\mathrm{b}}$ \\
\hline & Residual & 209.573 & 301 & .696 & & \\
\hline & Total & 242.806 & 302 & & & \\
\hline \multirow{3}{*}{2} & Regression & 37.394 & 2 & 18.697 & 27.306 & $.000^{\mathrm{c}}$ \\
\hline & Residual & 205.413 & 300 & .685 & & \\
\hline & Total & 242.806 & 302 & & & \\
\hline
\end{tabular}

a. Dependent Variable: Brand Loyalty

b. Predictors: (Constant), SMMA

c. Predictors: (Constant), SMMA, Brand_Love

The thresholds established in literature indicate that the $\mathrm{F}$ value should be above 1.96 in order for the research to be significant. The values are clearly above 1.96 in the table thus indicating that the research is significant.

The mean value, mentioned in the table above is computed by dividing sum of squares and degree of freedom. The values of both these tables are obtained by the first three tables that are sum of squares, degree of freedom and mean squares. The F-test value is calculated by dividing the mean square of the regression by the mean square of residual and indicates whether we should reject or not reject the null hypothesis proposed. The larger the value of $\mathrm{F}$, the more it is likely that the effect of the study is real and the null hypothesis is rejected.

\section{CONCLUSION}

This research was centered around examining the impact of social media marketing on establishing brand love and henceforth promoting brand loyalty in the restaurant landscape of Pakistan. The main aim is to view the impact of the independent variables namely, Word of Mouth, Trendiness and Customization on establishing brand love. The role of brand love as a mediating variable has also been examined. The results indicate a strong relationship between these variables and the dependent variable and all existing proposed hypotheses have been verified through data collection and analysis through SPSS.

At the point when the targeted customers see the advertisements on online channels and particularly on the social media, they will in common trust that the social media publicizing is enlightening, engaging, solid and dependable which drives them to create ideal discernments about the significance of promoting. Keeping in mind our 3 SMMA variables, Trendiness is imperative due to the ever-rising tide of restaurants popping up into existence in Pakistan. If a restaurants social media is trendy and it is considered 'cool' to use their particular social media platform as a form of self-reflection at a subconscious level, customers will tend to engage more with the advertisements thus leading to higher conversions. For example, whenever the popular restaurant brand 'Howdy' posts a picture of its customers wearing its signature themed cowboy hats, more and more people are given the incentive to post pictures of themselves wearing the hats. The rustic cowboy themed restaurant was a standout amongst all competition and thus this transient advantage helped them make their place in the marketplace.

Social acceptance is a craving that most humans cannot live without, thus as marketers, it is up to us to create an environment where a person cannot live without being a part of our revolution. They would hop aboard the trend and thus this would lead 
to our next variable which is Word of Mouth. This is perhaps one of the most crucial variables for the success of any business. Pertaining to the restaurant industry, this variable caters to many factors. Most importantly the questionnaire was designed in much detail to oversee whether the customer was comfortable enough writing a good review of the restaurant and sharing it to their profile or blog. This question was designed with the target at getting the result of the most intimate level of the consumer touch point, i.e. do they feel that this particular restaurant is worth recommending? Are consumers confident enough with this brand to choose it to reflect their personality?

WOM is one of the most effective variables since consumers feel more confident about a brand recommendation when it comes from someone they know. The trust factor is much more heavily involved in a personal recommendation.

The brand managers of organization can take in the procedures to viably plan distinctive ad related exercises via Social media; for example, using powerful data analysis and using engagement techniques, brands can snatch more group of onlookers and increment their deals and improve their brand dependability. It can enable managers to successfully deal with their brand and impart their message to their intended interest group, It will likewise enable them to have a superior comprehension of the purchasers' demeanor towards their advertisement

Similarly, it likewise helps them to have a comprehension on the best way to enhance their brand positioning which will affect the frame of mind of the buyers decidedly, and subsequently increment the brand love and loyalty element of the customers. The discoveries of this investigation may end up being useful for influencing the potential clients, explicitly in light of the fact that a large portion of the clients previously purchasing an item check for its information on the web, and invest a large portion of their energy in various fan pages accessible via web-based networking media, for example, Facebook, Instagram, Snapchat. To impact a large number of clients who put in day and night on web-based systems administration destinations, organizations require multidimensional and distinctive sorts of promoting methods to pull in and gain the consideration of focus and in addition potential clients.

\section{FUTURE STUDIES AND RECOMMENDATIONS}

Entertainment and Interaction are two further variables addressed in literature in the framework of the social media strategies and it is recommended to involve these in future research. The role of self-expressive brands has also been discussed in literature and involving that aspect within the context of social media would be an interesting avenue to explore in the future. Mediating roles can be examined thoroughly and much insight can be developed from the wealth of knowledge at our disposal through various tools.

Big data is playing an increasingly imperative role towards establishing consumer profiles for marketing data and thus elements of brand love can be further looked into detail. Analytics can be taken into consideration and scrutinized in detail. Due to limitations of the researcher, this research was limited to establishing the effect of three major independent variables and further work can be done upon compounding these research findings and adding more input to it since social media is a vast topic and consumer actions are always changing and developing, thus research needs to adapt itself accordingly. The research could be further enhanced by looking into all aspects of Brand love and loyalty and by including variables such as entertainment and interaction in the context of social media. 


\section{REFERENCES}

Aiello, G., Giovino, I., Vallone, M., \& Catania, P. (2017). A multi objective approach to short food supply chain management. Chemical Engineering Transactions, 313-318.

Albert, N., Merunka, D., \& Valette-Florence, P. (2008). When consumers love their brands: exploring the concept and its dimensions. Journal of Business Research, 1062-1075. https://doi.org/10.1016/j.jbusres.2007.09.014

Algharabat, R. S. (2017). Linking social media marketing activities with brand love. Kybernetes, 46(10), 1801-1819. https://doi.org/10.1108/K-04-2017-0130

Batra, R., Ahuvia, A., \& Bagozzi, R. P. (2012). Brand love. Journal of marketing. https://doi.org/10.1509/jm.09.0339

Du, S., \& Vieira, E. T. (2012). Striving for legitimacy through corporate social responsibility: Insights from oil companies. Journal of Business Ethics. https://doi.org/10.1007/s10551-012-1490-4

Edalat, N., \& Morris, H. (n.d.). Impact of Social Media in the restaurant industry. Emirates Academy of Hospitality Management.

Elghannam, A., Arroyo, J., Eldesouky, A., \& Mesias, F. J. (2018). A cross-cultural consumers' perspective on social media-based short food supply chains. British Food Journal, 2210-2221. https://doi.org/10.1108/BFJ-11-2017-0633

Hair Jr, J. F., Hult, G. T. M., Ringle, C. \& Sarstedt, M. (2016). A Primer on Partial Least Squares Structural Equation Modeling (PLS-SEM), Sage Publications. https://doi.org/10.15358/9783800653614

Haque, J., \& Popalzai, S. (2013, March 20). Pakistan Internet Use Survey. Retrieved from https:/tribune.com.pk/story/591004/pakistan-internet-use-survey-2013/

Kaufmann, H. R., Loureiro, S. M., \& Manarioti, A. (2016). Exploring behavioural branding, brand love and brand co-creation. Journal of Product \& Brand Management, 516-526. https://doi.org/10.1108/JPBM-06-2015-0919

Kemp, S. (2016). We are social's compendium of global digital, social, and mobile data, trends, and statistics. We are social. https://doi.org/10.1108/03090561211202521

Kerr, G., Mortimer, K., Dickinson, S., \& Waller, D. S. (2012). Buy, boycott or blog: Exploring online consumer power discuss and distribute controversial advertising message. European Journal of Marketing.

Kohli, G., Melewar, T., \& Yen, D. (2014). Investigating the strategic marketing significance of brand love in developing and nurturing consumer-brand relationships via film branding: a brandscape perspective. The Marketing Review, 383-405. https://doi.org/10.1362/146934714X14185702841325

Langner, T., Bruns, D., Fischer, A., \& Rossiter, J. (2016). Falling in love with brands: a dynamic analysis of the trajectories of brand love. Marketing Letters, 15-26. https://doi.org/10.1007/s11002-014-9283-4

Lee, H. H., Van Dolen, W., \& Kolk, A. (2013). On the role of social media in the 'responsible' food business: Blogger buzz on health and obesity issues. Journal of business ethics, 695-707. https://doi.org/10.1007/s10551-013-1955-0

Møller Jensen, J., \& Hansen, T. (2006). An empirical examination of brand loyalty. Journal of Product \& Brand Management, 442-449. https://doi.org/10.1108/1061042 0610712829

Mundler, P., \& Laughrea, S. (2016). The contributions of short food supply chains to territorial development: a study of three Quebec territories. Journal of Rural Studies, 218-229. https://doi.org/10.1016/j.jrurstud.2016.04.001 
Nguyen, T. D., Barrett, N. J., \& Miller, K. E. (2011). Brand loyalty in emerging markets. Marketing Intelligence \& Planning, 222-232. https://doi.org/10.1108/0263450111112 9211

Schmitt, B. (2012). The consumer psychology of brands. Journal of Consumer Psychology, 7-17. https://doi.org/10.1016/j.jcps.2011.09.005

Sternberg, R. (1997). Construct validation of a triangular love scale. European Journal of Social Psychology, 313-335. https://doi.org/10.1002/(SICI)1099-0992(199705)27:3< 313::AID-EJSP824>3.0.CO;2-4

Vernuccio, M., Pagani, M., Barbarossa, C., \& Pastore, A. (2015). Antecedents of brand love in online network based communities: a social identity perspective. Journal of Product \& Brand Management, 706-719. https://doi.org/10.1108/JPBM-12-2014-0772

Virginia Phelan, K., Chen, H. T., \& Haney, M. (2013). "Like" and "Check-in": how hotels utilize Facebook as an effective marketing tool. Journal of hospitality and Tourism Technology, 134-154. https://doi.org/10.1108/JHTT-Jul-2012-0020

Wallace, E. B., \& de Chernatony, L. (2014). Consumer engagement with self-expressive brands: brand love and WOM outcomes. Journal of Product \& Brand Management, 33-42. https://doi.org/10.1108/JPBM-06-2013-0326

Wallace, E., Buil, I., \& de Chernatony, L. (2017). Consumers' self-congruence with a "liked" brand: cognitive network influence and brand outcomes. European Journal of Marketing, 367-390. https://doi.org/10.1108/EJM-07-2015-0442

Wilson, R. E., Gosling, S. D., \& Graham, L. T. (2012). A review of Facebook research in the social sciences. Perspectives on psychological science, 203-220. https://doi.org/10. 1177/1745691612442904

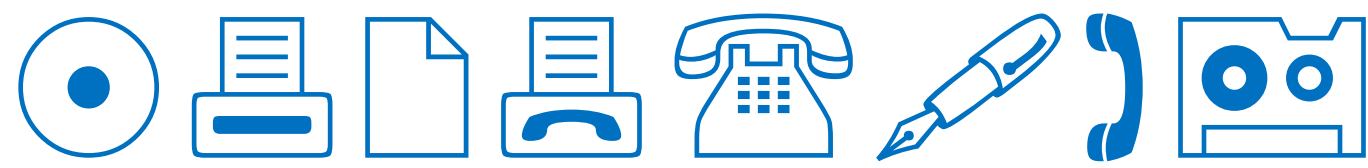

